\title{
PROFIL KANDIDOSIS INTERTRIGINOSA DI POLIKLINIK KULIT DAN KELAMIN BLU RSUP PROF. DR. R. D. KANDOU MANADO PERIODE JANUARI - DESEMBER 2012
}

\author{
Samuel Rian Wowor ${ }^{1}$ \\ Herry E. J. Pandaleke ${ }^{2}$ \\ Marlyn Grace Kapantow ${ }^{2}$ \\ ${ }^{1}$ Kandidat Skripsi Fakultas Kedokteran Universitas Sam Ratulangi Manado \\ ${ }^{2}$ Bagian/SMF Kulit dan Kelamin RSUP Prof. Dr. R. D. Kandou Manado \\ Email: samuel22rian@gmail.com
}

\begin{abstract}
Intertriginous Candidosis is a superficial mycoses affecting skin folds caused by yeast of the genus Candida, mostly Candida albicans. The purpose of this study was to evaluate the profile of intertriginous candidosis in Dermatovenereology clinic of Prof. Dr. R. D. Kandou Hospital Manado during the period from January - December 2012. This study was conducted retrospectively on medical records of new patients diagnosed with intertriginous candidosis in Dermatovenereology clinic of Prof. Dr. R. D. Kandou Hospital Manado during the period from January - December 2012. The result of this study showed that there were 37 patients (3.37\%) with intertriginous candidosis among 1096 new patients, significantly higher in female (64.86\%) than in male patients, highest rate recorded was within 45-64 age group (45.95\%), most skin fold affected was groin (16.22\%), and the most commonly used therapy was a combination of topical antifungal and oral antihistamine (29.74\%).
\end{abstract}

Keywords: superficial mycoses, intertriginous candidosis, retrospective study

\begin{abstract}
Abstrak
Kandidosis Intertriginosa merupakan mikosis superfisialis yang terkena pada daerah lipatan kulit yang disebabkan oleh jamur dari genus Candida umumnya Candida albicans. Tujuan penelitian ini adalah untuk mengetahui profil kandidosis intertriginosa di poliklinik Kulit dan Kelamin RSUP Prof. Dr. R. D. Kandou Manado periode Januari - Desember 2012. Penelitian ini dilakukan secara retrospektif dari rekam medik pasien baru dengan diagnosis kandidosis intertriginosa di Poliklinik Kulit dan Kelamin RSUP Prof. Dr. R. D. Kandou Manado periode Januari - Desember 2012. Hasil penelitian ini menunjukkan bahwa ada 37 pasien (3,37\%) kandidosis intertriginosa dari 1096 pasien baru, lebih banyak ditemukan pada perempuan dibanding laki-laki, kelompok umur terbanyak pada 45-64 tahun, lokasi lipatan kulit paling banyak terkena pada lipat paha, dan terapi yang paling banyak digunakan adalah antifungi topikal dan antihistamin.
\end{abstract}

Kata Kunci: mikosis superfisialis, kandidosis intertriginosa, penelitian retrospektif 
Kandidosis merupakan salah satu dermatomikosis superfisialis yang sering terkena pada manusia, yang disebabkan oleh jamur dari genus Candida, biasanya Candida albicans. ${ }^{1,3}$ Candida merupakan jamur komensal yang hidup dalam rongga mulut, saluran pencernaan, vagina, dan kulit. Akan tetapi, dalam keadaan tertentu seperti pada orang dengan gangguan imun atau terapi imunosupresi, Candida dapat menjadi patogen dan menyebabkan kandidosis. Inilah sebabnya kandidosis disebut jamur patogen oportunistik. ${ }^{3}$

Penyakit ini terdapat di seluruh dunia, relatif umum di daerah tropis, menyerang semua umur baik laki-laki maupun perempuan. Gambaran klinisnya beraneka macam sehingga tidak diketahui data-data penyebarannya dengan tepat. ${ }^{1,4}$ Conant $\mathrm{dkk}(1971)^{1}$ membaginya sebagai berikut kandidosis selaput lendir, kandidosis kutis, dan kandidosis sistemik.

Infeksi kandida dapat terjadi apabila terdapat faktor predisposisi seperti kehamilan (perubahan $\mathrm{pH}$ vagina), hiperhidrosis, obesitas, diabetes melitus, gangguan imunitas, orang tua, bayi, penderita kanker, terapi imunosupresan, penyakit kronik (Lupus Eritematosus dan Tuberkulosis). Penggunaan antibiotik jangka panjang serta lingkungan dengan suhu dan kelembaban tinggi, berkecimpung pada pekerjaan yang basah dan pekerjaan dengan bahan iritan juga turut berperan menjadikan jamur ini tumbuh subur dan bersifat patogen. ${ }^{1,5}$ Peningkatan jumlah penderita HIV/AIDS, meningkatnya penggunaan antibiotik oleh masyarakat tanpa berkonsultasi dengan tenaga kesehatan, juga perubahan iklim menjadi semakin panas yang menyebabkan seseorang lebih sering berkeringat, dapat memicu terjadinya peningkatan jumlah kasus dari kandidosis intertriginosa.

Penelitian yang dilakukan di National Skin Centre, Singapura, dari tahun 1999-2003 menempatkan Kandidosis (11,1\%) pada urutan ketiga kasus mikosis terbanyak setelah dermatofitosis $(57 \%)$ dan pitiriasis versikolor $(25,2 \%) .{ }^{6}$ Dari seluruh kasus kandidosis yang ditemukan, kandidosis intertriginosa merupakan kasus terbanyak (69,8\%). Hal ini disebabkan karena faktor iklim di Singapura yang panas dan lembab. ${ }^{6}$ Hasil yang serupa juga ditemukan pada penelitian yang dilakukan di Bangladesh, dimana kandidosis menempati urutan ketiga dari infeksi jamur superfisial. ${ }^{7}$ Dari seluruh kasus kandidosis yang ditemukan, oral thrush paling umum ditemukan dan diikuti oleh kandidosis intertriginosa.

Penelitian mengenai kandidosis kutis pada suatu provinsi di Irak menunjukkan persentase kandidosis kutis sebanyak 26,2\% dari seluruh infeksi jamur pada kulit. Distribusi dari kandidosis kutis menunjukkan kandidosis intertriginosa secara signifikan lebih tinggi (62,9\%) dibanding dengan bagian kulit lain. Mengenai hubungan dengan jenis kelamin, kandidosis intertriginosa paling banyak terkena pada wanita $(64 \%)^{8}$

Seru RS (2012) ${ }^{9}$ dalam penelitiannya di RSUP Prof. Dr. R. D. Kandou melaporkan bahwa pada tahun 2009-2011, kasus kandidosis kutis memiliki persentase sebesar 8,92\% dari seluruh penyakit jamur, dengan kandidosis intertriginosa merupakan kasus kandidosis terbanyak (95,63\%).

Berdasarkan latar belakang di atas, dapat disimpulkan bahwa kandidosis intertriginosa merupakan infeksi jamur pada kulit yang umum ditemukan dengan persentase yang tinggi pada kasus kandidosis kutis. ${ }^{1,4}$ Oleh sebab itu, peneliti tertarik untuk melakukan penelitian tentang profil kandidosis intertriginosa di RSUP Prof. Dr. R. D. Kandou.

\section{METODE PENELITIAN}

Penelitian ini merupakan penelitian deskriptif retrospektif yang dilakukan di Poliklinik Kulit dan Kelamin RSUP Prof. Dr. R. D. Kandou Manado dengan data diperoleh dari rekam medik pasien 
periode Januari-Desember 2012. Penelitian ini dilakukan selama bulan November 2013 sampai Desember 2013.

Populasi mencakup seluruh data pasien baru yang berobat di Poliklinik Kulit dan Kelamin RSUP Prof. Dr. R. D. Kandou Manado periode Januari 2012 - Desember 2012. Sampel penelitian yang diambil yaitu seluruh data pasien yang didiagnosis kandidosis intertriginosa di Poliklinik Kulit

dan Kelamin RSUP Prof. Dr. R. D. Kandou Manado periode Januari 2012 - Desember 2012. Variabel penelitian yang diambil adalah umur, jenis kelamin, lokasi, dan jenis pengobatan.

\section{HASIL PENELITIAN}

Penelitian yang dilakukan secara retrospektif dari bulan November-Desember 2013 pada penderita dengan diagnosis kandidosis intertriginosa di Poliklinik Kulit dan Kelamin RSUP Prof Dr. R. D. Kandou Manado periode Januari 2012 - Desember 2012 memberikan hasil sebagai berikut:

Tabel 1. Distribusi angka kejadian kandidosis intertriginosa

\begin{tabular}{ccc} 
Jumlah Pasien di Poliklinik & Penderita Kandidosis Intertriginosa & Persentase \\
\hline 1096 & 37 & $3,37 \%$
\end{tabular}

Tabel 1 menunjukkan bahwa terdapat 37 pasien didiagnosis dengan kandidosis intertriginosa dari total 1096 pasien baru dengan persentase sebesar 3,37\%.

Tabel 2. Distribusi kandidosis intertriginosa menurut jenis kelamin

\begin{tabular}{lcc}
\hline \multicolumn{1}{c}{ Jenis Kelamin } & Jumlah & Persentase \\
\hline Laki-Laki & 13 & $35,14 \%$ \\
Perempuan & 24 & $64,86 \%$ \\
\hline Total & 37 & $100 \%$ \\
\hline
\end{tabular}

Tabel 2 menunjukkan bahwa kandidosis intertriginosa paling banyak terkena pada perempuan, yaitu 24 kasus dari 37 kasus dengan persentase sebesar 64,86\%. Sedangkan pada pria terdapat 14 kasus (35,14\%).

Tabel 3. Distribusi kandidosis intertriginosa menurut kelompok umur

\begin{tabular}{ccc}
\hline Umur (tahun) & Jumlah & Persentase \\
\hline$<1$ & 0 & $0 \%$ \\
$1-4$ & 0 & $0 \%$ \\
$5-14$ & 3 & $8,11 \%$ \\
$15-24$ & 2 & $5,40 \%$ \\
$25-44$ & 7 & $18,92 \%$ \\
$45-64$ & 17 & $45,95 \%$ \\
$\geq 65$ & 8 & $21,62 \%$ \\
\hline Total & 37 & $100 \%$ \\
\hline
\end{tabular}

Tabel 3 menunjukkan bahwa kelompok umur 45-64 tahun merupakan kelompok umur yang paling banyak menderita kandidosis intertriginosa (45,95\%), kemudian diikuti oleh kelompok umur $\geq 65$ tahun $(21,62 \%)$. Tidak ada pasien pada kelompok umur $<1$ tahun dan $1-4$ tahun $(0 \%)$. 
Tabel 4. Distribusi lokasi lipatan kulit yang terkena kandidosis intertriginosa

\begin{tabular}{|c|c|c|}
\hline Lokasi & Jumlah & Persentase \\
\hline Ketiak & 3 & $8,12 \%$ \\
\hline Ketiak + Lipat Payudara & 1 & $2,70 \%$ \\
\hline Ketiak + Lipat Payudara + Leher & 1 & $2,70 \%$ \\
\hline Ketiak + Lipat Payudara + Lipat Perut & 1 & $2,70 \%$ \\
\hline Leher + Pusar & 1 & $2,70 \%$ \\
\hline Lipat Payudara & 1 & $2,70 \%$ \\
\hline Lipat Perut & 3 & $8,12 \%$ \\
\hline Pusar & 1 & $2,70 \%$ \\
\hline Sela Jari Kaki & 2 & $5,40 \%$ \\
\hline Sela Jari Tangan & 1 & $2,70 \%$ \\
\hline Sela Jari Tangan + Sela Jari Kaki & 1 & $2,70 \%$ \\
\hline Lipat Paha & 6 & $16,22 \%$ \\
\hline Lipat Paha + Leher & 1 & $2,70 \%$ \\
\hline Lipat Paha + Kaki & 1 & $2,70 \%$ \\
\hline Lipat Paha + Ketiak & 5 & $13,52 \%$ \\
\hline Lipat Paha + Lipat Bokong & 1 & $2,70 \%$ \\
\hline Lipat Paha + Lipat Payudara & 3 & $8,12 \%$ \\
\hline Lipat Paha + Lipat Perut & 2 & $5,40 \%$ \\
\hline Lipat Paha + Lipat Perut + Lipat Payudara & 1 & $2,70 \%$ \\
\hline Lipat Paha + Lipat Perut + Leher & 1 & $2,70 \%$ \\
\hline Total & 37 & $100 \%$ \\
\hline
\end{tabular}

Berdasarkan tabel 4, dapat dilihat bahwa lipat paha merupakan lokasi lipatan kulit yang paling sering muncul dengan persentase sebesar 16,22\%, diikuti oleh lipat paha + ketiak $(13,52 \%)$.

Tabel 5. Terapi obat yang diberikan pada pasien kandidosis intertriginosa

\begin{tabular}{|c|c|c|}
\hline Terapi Obat & Jumlah & Persentase \\
\hline Antifungi topikal & 2 & $5,40 \%$ \\
\hline Antifungi topikal + Antibiotik oral & 1 & $2,70 \%$ \\
\hline Antifungi topikal + Antibiotik oral + Antibiotik topikal & 1 & $2,70 \%$ \\
\hline $\begin{array}{l}\text { Antifungi topikal + Antibiotik oral + Antibiotik topikal + } \\
\mathrm{NaCl}+\text { NSAID + PPI }\end{array}$ & 1 & $2,70 \%$ \\
\hline Antifungi topikal + Antihistamin oral & 11 & $29,74 \%$ \\
\hline Antifungi topikal + Antihistamin oral + Antibiotik topikal & 6 & $16,22 \%$ \\
\hline Antifungi topikal + Antihistamin oral + Antibiotik topikal + & & \\
\hline Kortikosteroid topikal & 1 & $2,70 \%$ \\
\hline $\begin{array}{l}\text { Antifungi topikal + Antihistamin oral + Antibiotik topikal + } \\
\mathrm{NaCl}\end{array}$ & 1 & $2,70 \%$ \\
\hline Antifungi topikal + Antihistamin oral + Antifungi oral & & \\
\hline Antifungi topikal + Antihistamin oral + Kortikosteroid & 1 & $2,70 \%$ \\
\hline topikal & 10 & $27,04 \%$ \\
\hline Antifungi topikal + Antihistamin oral $+\mathrm{NaCl}$ & & \\
\hline Antifungi topikal + Kortikosteroid topikal & 1 & $2,70 \%$ \\
\hline & 1 & $2,70 \%$ \\
\hline Total & 37 & $100 \%$ \\
\hline
\end{tabular}


Tabel 5 menunjukkan bahwa kombinasi obat yang paling sering diberikan pada pasien kandidosis intertriginosa adalah antifungi topikal + antihistamin oral $(29,74)$. Kombinasi obat kedua terbanyak yang diberikan adalah antifungi topikal + antihistamin oral + kortikosteroid topikal $(27,04 \%)$.

\section{PEMBAHASAN}

Penelitian ini dilakukan dengan mengambil data rekam medik penderita kandidosis intertriginosa yang berobat di poliklinik RSUP Prof. Dr. R. D. Kandou Manado periode Januari 2012 - Desember 2012.

Berdasarkan hasil penelitian yang ada pada tabel 1, terdapat 37 pasien (3,37\%) didiagnosa kandidosis intertriginosa pada tahun 2012. Jika dibandingkan dengan penelitian yang dilakukan oleh Seru $\mathrm{RS}^{9}$, jumlah pasien kandidosis intertriginosa pada tahun 2011 tidak jauh berbeda dibanding pada tahun 2012 yaitu 38 pasien. Tidak adanya perubahan yang signifikan pada jumlah kasus dibanding dengan tahun 2011 dapat disebabkan karena perilaku masyarakat mengenai kesehatan kulit khususnya pada penyakit kandidosis intertriginosa belum ada perubahan. Namun jika dilihat dari tahun 2009, terdapat penurunan jumlah kasus dari 58 kasus menjadi 37 kasus atau sebesar 36,20\%. Penurunan jumlah kasus kandidosis intertriginosa dari tahun 2009 dapat disebabkan oleh beberapa faktor seperti meningkatnya kesadaran masyarakat terhadap kebersihan kulit dan pengendalian penyakit yang menjadi faktor risiko seperti diabetes melitus.

Pada distribusi penyakit menurut jenis kelamin, kasus kandidosis intertriginosa lebih banyak ditemukan pada perempuan dibanding laki-laki. Hasil ini juga serupa dengan hasil yang ditemukan pada suatu penelitian di Irak $^{8}$, Bangladesh ${ }^{7}$, dan penelitian yang dilakukan oleh Seru $\mathrm{RS}^{9}$. Hal ini dapat disebabkan karena beberapa faktor risiko yang dimiliki perempuan seperti tren berpakaian perempuan di masyarakat, yaitu pemakaian celana ketat pada iklim tropis yang akan menyebabkan produksi keringat yang banyak dan mengakibatkan lokasi lipatan-lipatan kulit yang tertutup pakaian menjadi lembab dan rentan terhadap infeksi kandidosis intertriginosa. Selain itu, perempuan juga memiliki lipatan pada dada, yaitu lipat payudara. Lipatan pada dada umumnya tidak ditemukan pada pria, kecuali pada pria obesitas.

Kandidosis intertriginosa paling banyak ditemukan pada kelompok umur 45-65 tahun (45,95\%) dan diikuti oleh kelompok umıئ 65 tahun (21,62\%). Ini disebabkan karena status imunologik pada orang yang tua sudah tidak sempurna lagi. Selain itu, orang-orang yang sudah tua rentan seseorang terhadap beberapa penyakit seperti diabetes melitus, yang merupakan faktor risiko dari kandidosis intertriginosa. Tidak terdapat kasus pada kelompok umur $<1$ tahun dan 1-4 tahun. Hal ini mungkin disebabkan karena kasus kandidosis intertriginosa pada kelompok umur ini telah ditangani di bagian anak.

Distribusi lokasi lipatan kulit yang terkena kandidosis intertriginosa memberikan hasil 16,22\% pasien terkena pada lipat paha saja. Jumlah kedua terbanyak ditemukan pada lipat paha + ketiak (13,52\%). Jika dari tiap-tipa lokasi lipatan kulit yang muncul, sebagian besar pasien memiliki lesi pada lipat paha. Hal ini dapat disebabkan karena lipat paha merupakan bagian yang paling tertutup saat seseorang berpakaian. Saat suhu lingkungan panas dan seseorang berkeringat, lipat paha menjadi bagian yang paling lembab karena keringat. Kondisi ini mendukung bertumbuhnya jamur kandida di lipat paha tersebut dan akhirnya menyebabkan kandidosis intertriginosa. Lokasi kedua terbanyak adalah ketiak. Ketiak merupakan bagian kulit yang lembab karena banyak mengeluarkan keringat. Jumlah kasus di lokasi ketiak tidak 
sebanyak lipat paha karena ketiak biasanya tidak tertutup dengan kain yang ketat seperti pada lipat paha.

Sebagian besar pasien hanya memiliki lesi pada satu lokasi lipatan kulit atau dua lokasi lipatan kulit yang terinfeksi kandidosis intertriginosa. Hanya sedikit pasien yang terkena lebih dari dua lokasi lipatan kulit. Hal ini disebabkan karena lesi di kulit pada pasien kandidosis intertriginosa memberikan rasa gatal, nyeri, dan bahkan dapat menimbulkan rasa terbakar, sehingga pasien cenderung langsung mencari pertolongan ke dokter sebelum lesi tersebut menyebar ke lokasi lipatan kulit yang lain.

Kombinasi obat yang paling sering digunakan adalah antifungi topikal + antihistamin oral (29,74\%). Terapi ini cukup untuk mengatasi infeksi jamur kandida pada kulit dan menangani gejala berupa rasa gatal pada lesi. Beberapa pasien dikombinasikan dengan kortikosteroid topikal (27,04\%). Hal ini menandakan bahwa ada beberapa pasien mendapat gejala yang lebih berat seperti timbul rasa terbakar dan nyeri, sebab kortikosteroid topikal diberikan untuk mengurangi gejala gatal, rasa terbakar, dan nyeri. ${ }^{4,10}$

Jika dilihat dari tiap jenis obat yang diberikan untuk terapi pasien, maka jenis obat yang paling banyak digunakan adalah antifungi azol topikal. Seluruh pasien kandidosis intertriginosa yang berobat di Poliklinik Kulit dan Kelamin diberikan antifungi azol topikal, karena penyakit kandidosis intertriginosa disebabkan oleh jamur, dan pilihan obat utama adalah antifungi azol topikal untuk menghilangkan penyebab infeksi tersebut. ${ }^{11-14}$ Jenis obat kedua terbanyak yang diberikan adalah antihistamin. Sebanyak 31 dari 37 pasien kandidosis intertriginosa mendapat terapi antihistamin. Pemberian antihistamin bertujuan untuk menghilangkan rasa gatal pada lesi di kulit. Rasa gatal merupakan gejala yang umum ditemukan pada kasus kandidosis intertriginosa. Oleh sebab itu, pemberian antihistamin sangat umum diberikan pada pasien kandidosis intertriginosa.

Pemberian antibiotik topikal maupun oral pada pasien menunjukkan bahwa telah terdapat infeksi sekunder pada pasien tersebut, sehingga dibutuhkan antibiotik untuk menghilangkan penyebab infeksi sekunder tersebut.

\section{SIMPULAN}

Berdasarkan hasil penelitian dan pembahasan pada penelitian ini, maka dapat diperoleh simpulan sebagai berikut:

1. Terdapat 37 kasus kandidosis intertriginosa (3,37\%) dari 1096 pasien di Poliklinik Kulit dan Kelamin RSUP Prof. Dr. R. D. Kandou Manado tahun 2012.

2. Kasus kandidosis intertriginosa lebih banyak pada perempuan $(64,86 \%)$.

3. Kelompok umur yang paling banyak kasus kandidosis intertriginosa adalah kelompok umur 45-64 tahun (45.95\%).

4. Lipat paha merupakan lokasi lipatan kulit yang paling sering terkena kandidosis intertriginosa (16,22\%).

5. Paling banyak pasien hanya terkena pada satu lokasi lipatan kulit saja.

6. Antifungi azol topikal merupakan obat yang selalu diberikan pada penderita kandidosis intertriginosa.

7. Kombinasi obat yang paling banyak diberikan adalah Antifungi azol topikal + Antihistamin oral $(29,74 \%)$. 


\section{SARAN}

berikut :

Berdasarkan simpulan di atas, maka penelitian ini memberikan beberapa saran sebagai

1. Perlu dilakukan penelitian lebih lanjut mengenai penyebab adanya perbedaan distribusi dari jenis kelamin, kelompok umur, dan lokasi lipatan kulit.

2. Perlu meningkatkan kelengkapan dalam pengisian status pasien sehingga penelitianpenelitian di kemudian hari dapat dengan mudah dilakukan.

3. Perlu adanya penelusuran dan pencatatan mengenai faktor risiko yang dimiliki tiap pasien, sehingga dapat dilakukan penelitian mengenai faktor risiko kandidosis intertriginosa di masa yang akan datang.

\section{UCAPAN TERIMA KASIH}

Terima kasih kepada dr. Renate T. Kandou, SpKK(K) selaku Dosen Penguji I dan dr. Nurdjannah J. Niode, SpKK selaku Dosen Penguji II, serta kepada semua pihak yang terlibat dalam penelitian ini baik secara langsung maupun tidak langsung.

\section{DAFTAR PUSTAKA}

1. Kuswadji. Kandidosis. Dalam: Ilmu Penyakit Kulit dan Kelamin. Edisi ke-6. Jakarta: FKUI; 2011.hal.106-9.

2. Ramali LM. Kandidiasis Kutan dan Mukokutan. Dalam: Bramono K, Suyoso S, Indriatmi W, Ramali LM, Widaty S, Ervianti E. Dermatomikosis Superfisialis. Edisi ke-2. Jakarta: FKUI; 2013.hal.100-19.

3. James WD, Berger TG, Elston DM. Candidiasis. In: Andrews' Diseases of the Skin Clinical Dermatology. 11th ed. Saunders Elsevier; 2011. 297-99.

4. Havlickova B, Czaika VA, Friedrich M. Epidemiological trends in skin mycoses worldwide. Journal compilation Blackwell Publishing Ltd. 2008;51(4): 2-15.

5. Heymann DL. Candidiasis. In: Control of Communicable Disease Manual. 18th ed. American Public Health Association. 2011. 91-3.

6. Hiok-Hee T. Superficial Fungal Infections Seen at the National Skin Centre, Singapore. Jpn J Med Mycol. 2005;46:77-80

7. Rahman MH, Hadiuzzaman Md, Jaman MK, Bhuiyan, Islam N, Ansari NP, et al. Prevalence of superficial fungal infections in the rural areas of Bangladesh. Iran J Dermatol. 2011;14:86-91.

8. Hasan ASH, Al-Duliami AA, Al-Azawi NS. The Rate of Cutaneous Candidiasis in Patients with Skin Mycoses in Baquba/Diyala Province Iraq. Iraqi J Comm Med. 2008,3:242-5.

9. Seru RS. Profil Kandidiasis Kutis di Poliklinik Kulit dan Kelamin RSUP Prof. Dr. R. D. Kandou Manado Periode 2009-2011.[skripsi]. Manado: Fakultas Kedokteran Universitas Sam Ratulangi; 2013.

10. Kundu RV, Garg A. Yeast infections: Candidiasis and Tinea (Pityriasis) Versicolor. In: Goldsmith LA, Katz SI, Gilchrest BA, Paller AS, Leffell DJ, Wolff K, editor. Fitzpatrick's Dermatology in General Medicine, 8th ed. McGraw-Hill Companies; 2007. 2298-307.

11. Janniger CK, Schwartz RA, Szepietowski JC, Reich A. Intertrigo and Common Secondary Skin Infections. American Family Physician. 2005;72:833-38.

12. Pappas PG, Rex JH, Sobel JD, Filler SG, Dismukes WE, Walsh TJ, et al. Guidelines for Treatment of Candidiasis. Clinical Infectious Diseases. 2004;38:161-89. 
13. Stevens DL, Bisno AL, Chambers HF, Everett ED, Dellinger P, Goldstein JC, et al. Practice Guidelines for the Diagnosis and Management of Skin and Soft-Tissue Infections. Clinical Infectious Diseases. 2005;41:1373-406.

14. Gawkrodger DJ. Fungal Infections. In: Dermatology. 3rd ed. Churchill Livingstone; 2002. 55. 